\title{
生体リズムを基盤にした医薬品の適正使用に関する臨床生化学的研究
}

\author{
小柳 悟
}

\section{Optimization of the Dosage Schedule for Sustaining Intrinsic Biological Rhythms}

\author{
Satoru KoYANAGI \\ Department of Biochemistry, Faculty of Pharmaceutical Sciences, Fukuoka University, \\ 8-19-1 Nanakuma, Jonan-ku, Fukuoka 814-0180, Japan
}

(Received May 14, 2003)

\begin{abstract}
One of the most indispensable biological functions for all living organisms is the circadian clock, which acts like a multifunctional timer to regulate the homeostatic system including sleep and wakefulness, hormonal secretions, and various other body functions in a 24-hour cycle. Recent molecular dissections of the circadian biological clock system have revealed that oscillation in the transcription of specific clock genes plays a central role in the generation of circadian rhythms. Several drugs can affect the expression of clock genes, resulting in alteration of the 24-hour rhythms in physiology and behavior. Here, we report the disruptive effect of interferon (IFN) on the core circadian oscillation mechanism. Treatment of cultured hepatic cells with IFN- $\alpha$ caused a significant reduction in Clock and Bmall mRNA levels, which are positive regulators of circadian output rhythm, leading to a decrease in their protein levels. The continuous administration of IFN- $\alpha$ significantly decreased CLOCK and BMAL1 protein levels in the suprachiasmatic nucleus and liver of mice, thereby preventing oscillations in the expression of clock and clock-controlled output genes. These findings reveal a possible pharmacologic action of IFN- $\alpha$ on the core circadian oscillation mechanism and indicate that the disruptive effect of IFN- $\alpha$ on circadian output function is the underlying cause of its adverse effects on 24-hour rhythms in physiology and behavior. Furthermore, the alteration of clock function, a new concept of adverse effects, can be avoided by altering the dosage schedule of IFN- $\alpha$ to minimize the adverse drug effect on clock gene expression. One approach for increasing the efficacy of pharmacotherapy is administering drugs at the time of day when they are best tolerated. Attention should be paid to the alteration of clock gene expression, and it should be considered an adverse effect when it leads to altered circadian organization of the molecular clockwork which is a serious problem affecting basic function of living organisms.
\end{abstract}

Key words — circadian rhythm; clock genes; chronopharmacology; interferon

\section{1.はじめに}

我々の身体には約 24 時間を 1 サイクルとする様 々な周期的現象が認められる. 睡眠・覚醒のサイク ルやコルゾール分泌などのリズムはその代表例であ るが，血圧や体温，各種の酵素活性やリンパ球の反 応性などにも 1 日を一周期とするリズム（日周リズ ム）が認められる。このような現象は外界からの時 間的手掛かりのない定常状況下でも認められること から生体内には自律的にリズムを発振する機能が存

福岡大学薬学部生化学教室 ( 七隈 8-19-1)

e-mail: koyanagi@cis.fukuoka-u.ac.jp

*本総説は, 平成 14 年度日本薬学会九州支部学術奨励 賞の受賞を記念して記述したものである.
在していることが分かる（体内時計）。実際，哺乳 類動物においては視床下部の視交叉上核に概日性リ ズムを発振するリズム中枢が存在し, 睡眠・覚醒の サイクルやホルモン分泌など多くの生体機能の日周 リズムを制御している. ${ }^{1)}$ また近年，哺乳類の体内 時計の振動体を構成する遺伝子として Clock, Bmal1, Period (Per1, Per2, Per3), Cryptochrome (Cry1, Cry2) などの時計遺伝子 (clock gene) が相 ついで同定され，生体リズム発振のメカニズムや外 界環境（明暗サイクル）への同調機構が分子レベル で明らかになりつつある. ${ }^{2-5)}$

体内時計機構は生物が外的環境の周期的変化に効 率良く対応すべく進化の過程で獲得した巧妙な仕組 みであり, 生命活動の維持において重要な働きを担 
つている，例えば，起床時に副腎皮質ホルモン分泌 の急激な上昇により, 我々は睡眠から醒め行動でき るように身体の体制が準備される。これに引き続き 交感神経の活動性が活発になり，眠りにつく頃には 副交感神経の活動性が優位になる。したがって, 神 経・内分泌・免疫機能など様々な生体機能に認めら れるこれらリズムは互いに調和を保ちながら生体の 恒常性維持に努めていると言える。一方，規則正し いリズムを保ちながら生活することが, 健康を保 持・増進する上でも重要であるように, 生体リズム の変容は我々の心身に様々な弊害を引き起こす。6,7) 実際，睡眠障害を伴う生体リズムの異常は，大きな 事故や判断ミスなどのヒューマンエラーの原因とな る. また一方で, 慢性的な生体リズムの変容は, 意 欲の低下や抑うつ状態などの精神疾患に結びつく可 能性が指摘されている. 生体リズムは光, 摂食, ス トレスなど様々な外的因子の影響を受け変化する が，筆者らは疾患の治療目的で使用される薬剤が時 計遺伝子の発現に影響を及ぼし，生体機能の日周リ ズムを変容させることを明らかにした。

インターフェロン $-\alpha(\mathrm{IFN}-\alpha)$ はウイルス性慢性 肝炎などの治療薬として広く用いられているが，一 方で不眠や抑うつなど生体リズムの異常と関連の深 い副作用を引き起こすことが報告されている。この 原因については長い間不明であったが，我々はマウ スを用いた基礎実験において，IFN- $\alpha$ は生体リズム 中枢である視交叉上核での時計遺伝子の発現に影響 を及ぼし，体内時計の働きを低下させることを明ら かにした. ${ }^{8,9)}$ 本稿ではこれら研究内容について概説 し, 最近の我々の知見についても併せて紹介する.

2. 体内時計の分子機構とリズム発振のメカニズ

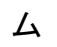

近年の分子生物学の発展に伴い, 視交叉上核の神 経細胞において一連の遺伝子群（時計遺伝子）が約 24 時間周期で発現の増減を繰り返すことが, リズ 厶発振の中心的機構であることが明らかになってき た。時計遺伝子の発現はほぼ全身の組織で認められ るが，視交叉上核においてより強い発現を示す。実 験的に視交叉上核を破壊した動物では, 活動期・休 息期の行動リズムパターンが不明瞭になるのと同時 に末梢組織における時計遺伝子の発現リズムも消失 する.このことから体内時計機構は視交叉上核がマ スター時計として働き, 未梢組織におけるローカル
時計の機能をコントロールするという階層的構造で 成立していると考えられている. ${ }^{10,11)}$

時計遺伝子の改変動物やノックアウトマウスを用 いた解析などから，哺乳類動物における体内時計の 本体（振動体）は, Fig. 1 に示すようなフィードバ ックループ機構であると考えられている. ${ }^{2,3)}$ この機 構によれば CLOCK/BMAL1 蛋白のへテロダイ マー体は E-box (CACGTG) と呼ばれる DNA 上の 特定の塩基配列に結合し, Per 及び Cry の各遺伝子 の発現を促進する。一方，産生された PER，CRY の各蛋白は互いに複合体を形成して核内に移行し, CLOCK/BMAL1 による自らの転写活性を抑制す る。また，視交叉上核における vasopressin 遺伝子 や肝臓における $d b p$ 遺伝子のようなリズム出力遺

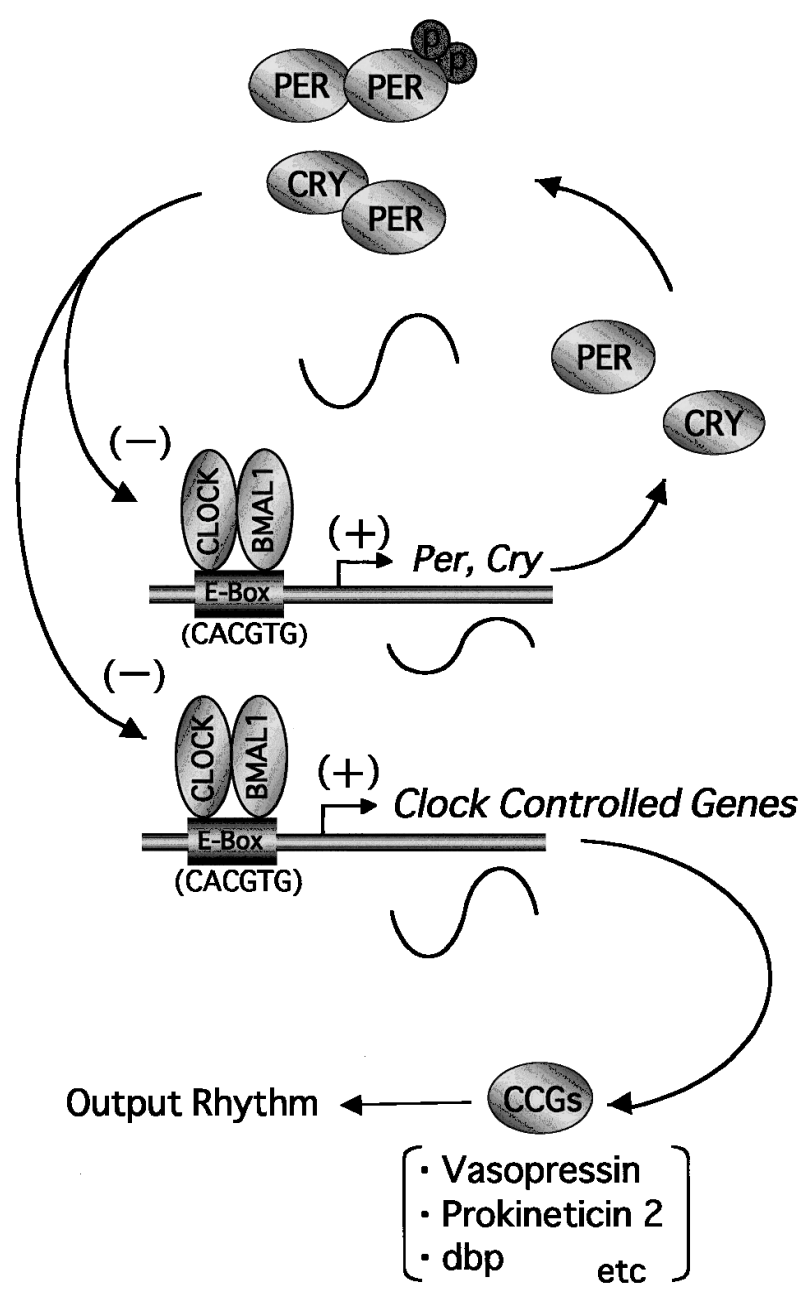

Fig. 1. Model of the Regulation of a Core Feedback Loop and Clock-Controlled Output Genes

Both positive (CLOCK and BMAL1) and negative (PER and CRY) transcriptional elements of the core feedback loop can also drive transcriptional rhythms in clock-controlled output genes (CCGs). 
伝子の転写活性はPer や Cry 遺伝子の場合と同様 にCLOCK/BMAL1の働きによって促進され， PER 及びCRY の各蛋白によって抑制される. ${ }^{12,13)}$ したがって, これら出力遺伝子の発現リズムは時計 遺伝子による直接的な制御下にあり，このようなフ イードバックループ機構こそが我々の身体の 24 時 間周期のリズムを発振する根源であると考えられて いる.

3. CLOCK 及び BMAL1 遺伝子の発現に及ぼす 影響

CLOCK と BMAL1 は生体リズムの発振には不可 欠な転写活性因子であり, そのどちらか一方の機能 が欠損するだけでも睡眠・覚醒サイクルなどの概日
性リズムに異変が生じる. ${ }^{14,15)}$ そこでまず，培養ヒ 卜肝細胞を用いて IFN- $\alpha$ が CLOCK と BMAL1の 発現にどのような影響を及ぼすかについて検討を行 つた．培養した HepG2 細胞に各濃度の IFN- $\alpha$ を作 用させ， mRNA 及び蛋白の発現レベルを RT-PCR 法, Western blot 法によって測定した。 その結果 CLOCK, BMAL1 の各 mRNA の発現レベルはとも に IFN- $\alpha$ の濃度依存的に減少し (Fig. 2A), これ ら蛋白の発現量も IFN- $\alpha$ の濃度依存的に減少した (Fig. 2B).

IFN- $\alpha$ は細胞膜上の特異的受容体に結合し, JAK-STAT シグナル伝達経路を介して生理作用を 発揮する。この際 STAT 蛋白は JAK kinase の働き
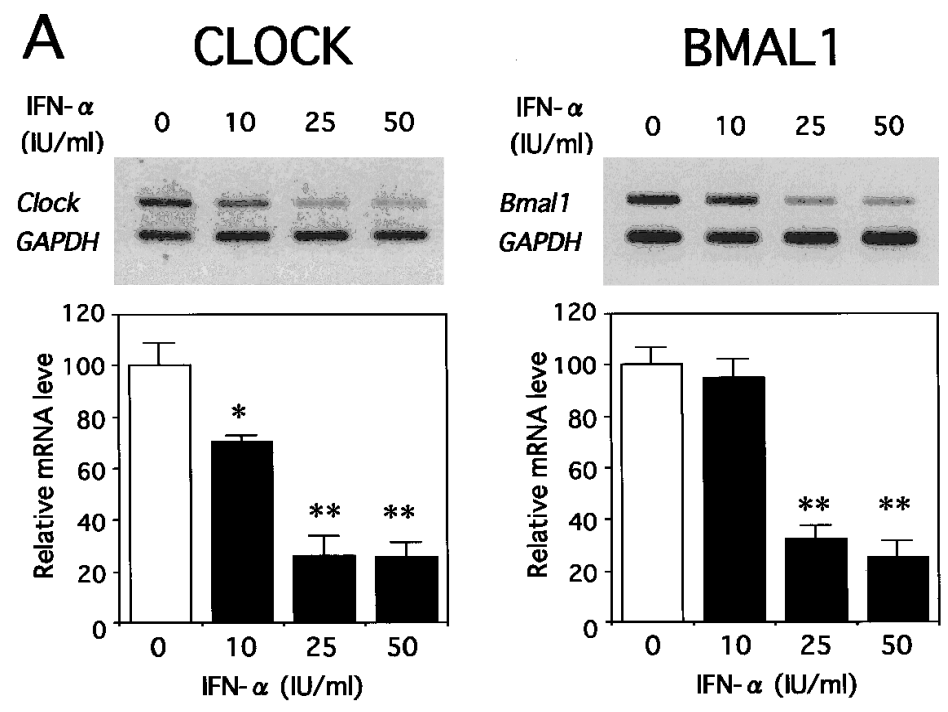

B
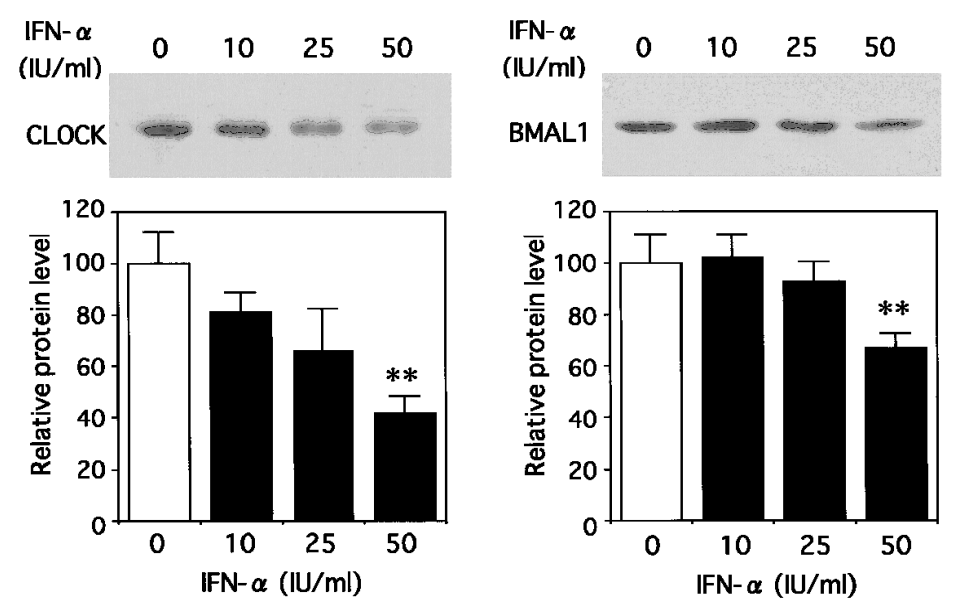

Fig. 2. The Effects of IFN- $\alpha$ on the Expression of CLOCK and BMAL1 mRNA (A) and Protein (B) in HepG2 Cells

Cells were treated with the indicated concentration of IFN- $\alpha$ for $72 \mathrm{hr}$. Total RNA and a cell nuclear fraction were prepared and analysed by RT-PCR and by immunoblotting, respectively. For plots of intensity, the mean value of the untreated group is set at 100 . Each value represents the mean \pm S.E.M. $(n=3)$. $* * p<$ $0.01,{ }^{*} p<0.05$ when compared with the untreated group (Dunnet test). 
によって C 末端のチロシン残基がリン酸化を受け 活性化される. ${ }^{16)}$ Fig. 3 に示すように, HepG2 細胞 を IFN- $\alpha$ に作用させたことにより STAT 蛋白のリ ン酸化は著しく克進した (lane 1 and 2). 一方, IFN- $\alpha$ のリガンドインヒビターである Aurintricarboxylic acid (ATA) は，濃度依存的に IFN- $\alpha$ による STAT1 蛋白のリン酸化を阻害し，これと同時に CLOCK, BMAL1 の各 mRNA の発現レベルは正常 レベルにまで回復した (lane 3-6)。これらの結果 から，IFN- $\alpha$ による CLOCK, BMAL1 の発現抑制 作用は，その特異的受容体や JAK-STAT シグナル 伝達経路の活性化を介した作用であることが示唆さ れた。

次に, IFN- $\alpha$ が生体リズム中枢である視交叉上核 での CLOCK, BMAL1の発現にも影響が及ぼすか について検討を行った。実験には自由摂食飲水・明 暗周期下 $(\mathrm{ZT}=$ zeitgeber time, $\mathrm{ZT} 0=$ light on, $\mathrm{ZT} 12$ $=$ light off）で飼育した ICR 雄性マウスを使用し た。浸透圧ミニポンプを用いて IFN- $\alpha$ を 7 日間持 続皮下投与（14 kI.U./hr） し，視交叉上核におけ る CLOCK, BMAL1 の各蛋白量を免疫組織染色法 で測定した. Saline 投与群における視交叉上核での CLOCK 蛋白の発現量には ZT6, ZT18 の両測定時 刻で有意な差異は認められなかったが, IFN- $\alpha$ 持続 投薬により両時刻における CLOCK 蛋白の発現量

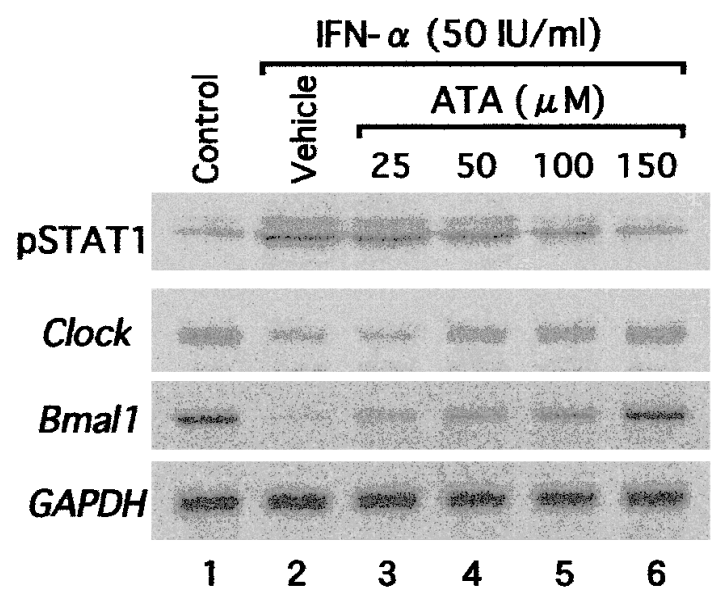

Fig. 3. The Disruptive Effect of IFN- $\alpha$ on Clock Gene Expression is Inhibited by a Competitive Ligand Inhibitor, ATA

Cells were treated for $72 \mathrm{hr}$ with $50 \mathrm{IU} / \mathrm{ml} \mathrm{IFN}-\alpha$ in the presence or absence (vehicle) of ATA at the indicated concentrations. A cell nuclear fraction was prepared and analysed for phosphorylated STAT1 protein (pSTAT1) by immunoblotting. Total RNA was also extracted and analysed for Clock and Bmall mRNA by RT-PCR analysis.
は有意に減少した。一方, Saline 投与群における BMAL1 蛋白の発現量は，ZT6 に比べZT18 におい て高值を示したが，IFN- $\alpha$ 持続投薬により ZT18に おける BMAL1 蛋白の発現量は有意に減少した (Fig. 4A).

また， Saline 投与群における肝臓での CLOCK, BMAL1 蛋白の発現量には測定時刻の違いによる有 意な差異は認められなかつたが，IFN- $\alpha$ 持続投薬に よりこれら蛋白の発現量はいずれの測定時刻におい ても有意に減少した (Fig. 4B)。これらのことから，

IFN- $\alpha$ は生体内においても培養細胞系で観察された 結果と同様に CLOCK, BMAL1 の発現量を減少さ せ，その作用は末梢組織のみならず，生体リズム中 枢である視交叉上核にまでも及ぶことが明らかにな つた.

4. 時計遺伝子及びリズム出力遺伝子の発現に及 ぼす影響

CLOCK, BMAL1 は互いにへテロダイマー体を 形成し，Per やCry などの時計遺伝子及び vasopressin や $d b p$ などのリズム出力遺伝子の転写 活性を促進する。 ${ }^{2,3,12,13)}$ そこで次に IFN- $\alpha$ による CLOCK, BMAL1 の発現レベルの減少がこれら遺 伝子の発現リズムにどのような影響を及ぼすかにつ いて検討を行った. IFN- $\alpha$ 持続投薬群における視交 叉上核でのPer1, Per2, Cryl 及び vasopressin 遺伝 子の発現リズムの振幅は Saline 投薬群に比べ有意 に減少した（Fig. 5A）。また肝臓におけるPerl 及 び $d b p$ 遺伝子も同様に発現リズムの振幅は著しく 低下した (Fig. 5B)。これらの結果から, IFN- $\alpha$ に よる CLOCK, BMAL1 の発現量の低下は, 時計遺 伝子やリズム出力遺伝子の発振を減弱させることが 明らかとなった。

5. 視交叉上核からのリズム出力及び行動リズム に及ぼす影響

これまでの変異動物やノックアウトマウスの解析 から時計遺伝子の変異や欠損は個体レベルでのリズ ム異常につながることが明らかになってい る. ${ }^{14,15,17-19)}$ そこで, IFN- $\alpha$ による時計遺伝子の発 現リズムの変容が個体レベルでの概日性リズムにも 影響を及ぼすかについて検討を行った。実験は視交 叉上核のリズム発振機能の指標として vasopressin 含量の日周リズムを睡眠・覚醒サイクルの指標とし て行動量のリズムを測定した. Saline 投与群におけ 
A

\section{CLOCK}
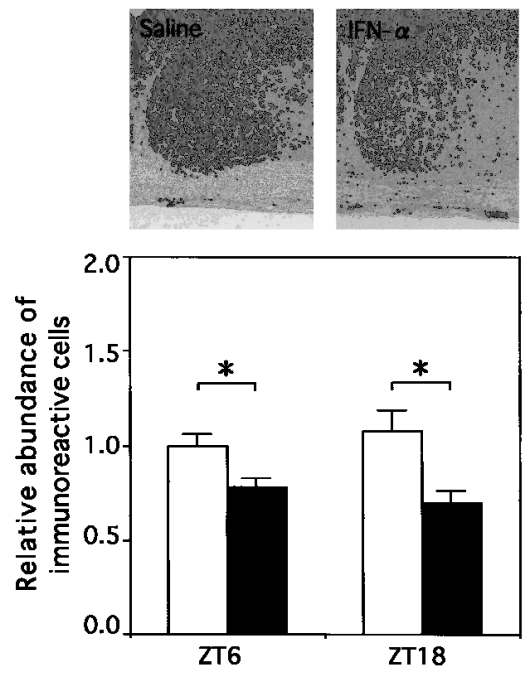

B
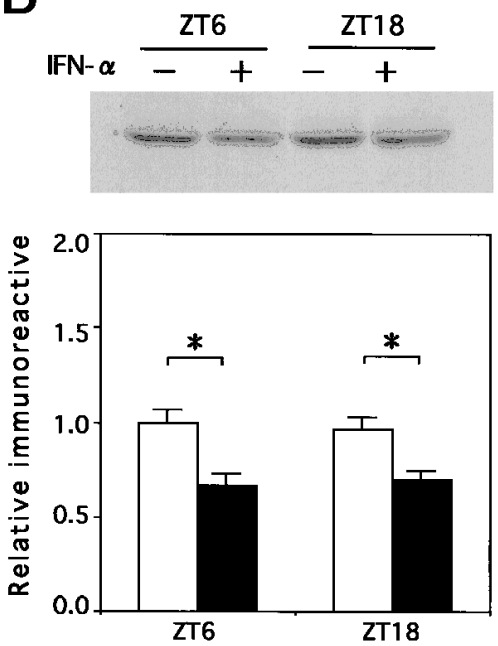

BMAL1
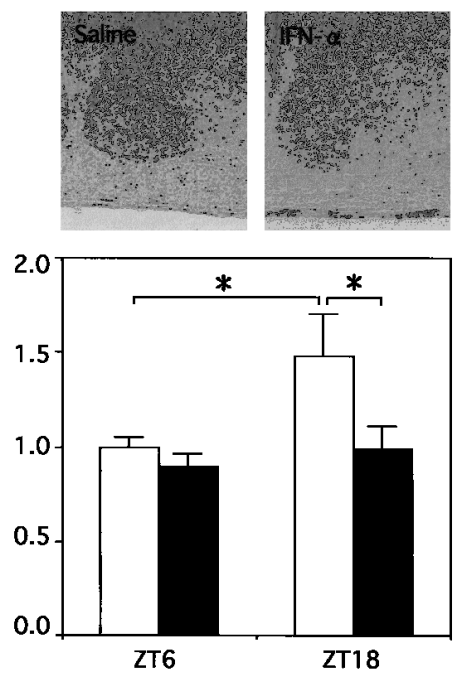
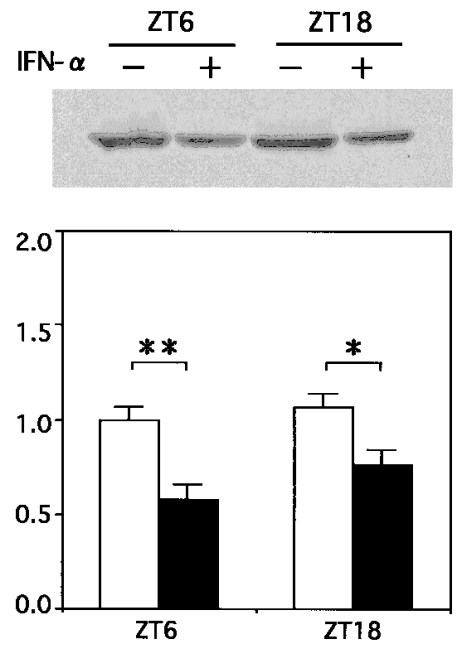

Fig. 4. CLOCK and BMAL1 Immunoreactivity in the SCN and Liver of IFN- $\alpha$-Treated Mice

A: Temporal profiles of CLOCK (left) and BMAL1 (right) immunoreactivity at ZT6 or ZT18 in the SCN of mice continuously administered IFN- $\alpha$ (14 k IU/ hr, s.c., $\mathbf{\square})$ or saline $(\square)$ using an osmotic minipump for 7 days. For plots of abundance, the mean value of immunoreactive cells in the SCN of control group at ZT6 is set at 1.0. Each value represents the mean \pm S.E.M. $(n=3-4) .{ }^{*} p<0.05$ when compared between the two groups (Tukey's test). The photomicrographs (upper) show immunoreactivity of CLOCK and BMAL1 at ZT18 in the SCN of saline or IFN- $\alpha$-treated mice. B: Temporal profiles of CLOCK (left) and BMAL1 (right) immunoreactivity at ZT6 or ZT18 in the liver of mice continuously administered IFN- $\alpha$ (14 k IU/hr, s.c., $\square$ ) or saline ( $\square$ ) using osmotic minipumps for 7 days. For plots of intensity, the mean value of the control group at ZT6 is set at 1.0. Each value represents the mean \pm S.E.M. $(n=3-4) .{ }^{* *} p<0.01,{ }^{*} p<0.05$ when compared between the two groups (Tukey's test). The upper panels illustrate immunoblots of CLOCK and BMAL1 proteins at ZT6 or ZT18 in the liver of saline or IFN- $\alpha$-treated mice.

る視交叉上核での vasopressin 含量には明期に高值 を暗期に低值を示す有意な日周リズムが認められた が，IFN- $\alpha$ 投与群ではいずれの測定時刻においても vasopressin 含量は低值を示し，その概日性リズム は消失した（Fig. 6A）。また, Saline 投与群におけ るマウスの行動には主に夜間において活動が活発と なる明瞭な日内変動が認められるが, IFN- $\alpha$ 投与群 においては 1 日あたりの行動量が減少し, 活動期・
休息期の時間帯が不明瞭になった (Fig. 6B)。これ らの結果から IFN- $\alpha$ による時計遺伝子の発現リズ ムの変容は, 視交叉上核からのリズム発振力を減弱 させ, 睡眠・覚醒サイクルなどの生体機能の日周リ ズムにも影響を及ぼすことが明らかになった。

6. 時計遺伝子の発現に及ぼす IFN- $\alpha$ 投薬タイ ミングの影響

過去に, 我々は IFN- $\alpha$ の抗ウイルス効果や発熱 
A

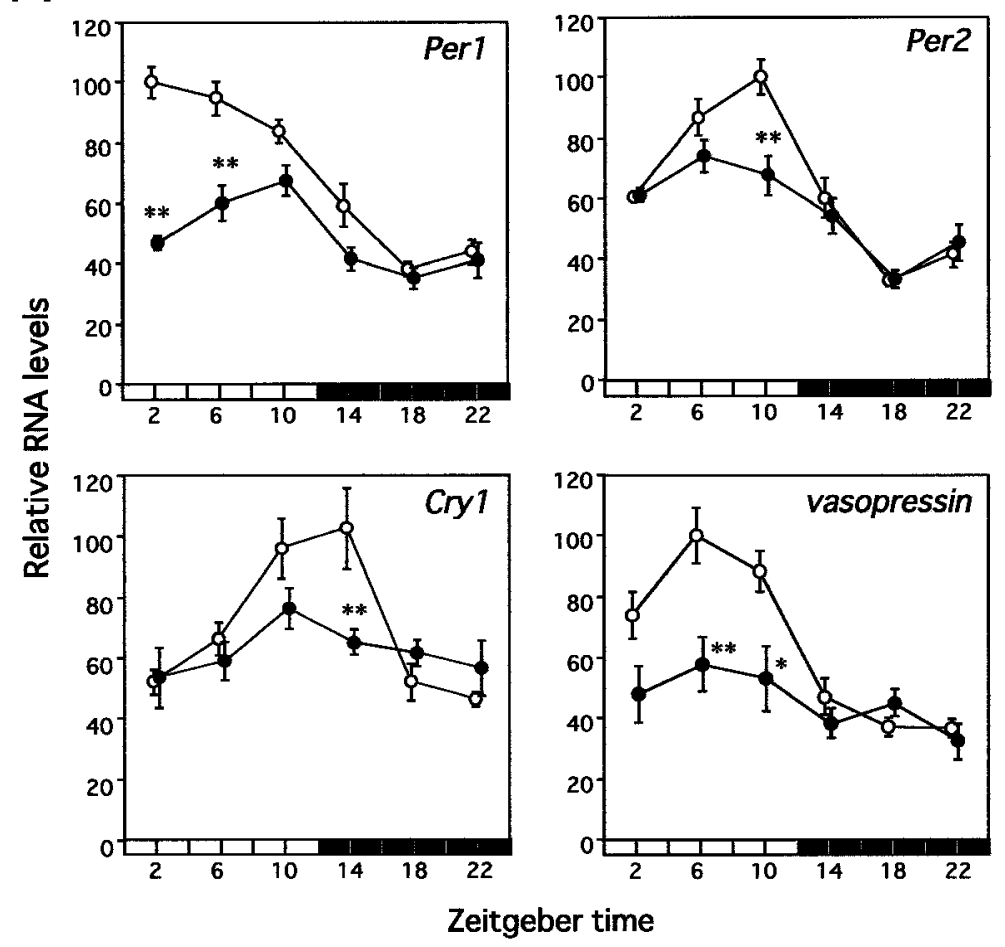

B
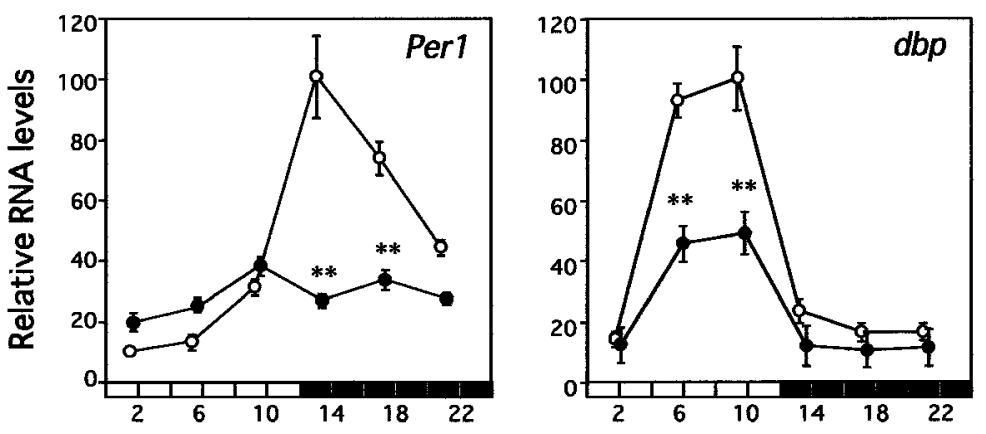

Zeitgeber time

Fig. 5. Influence of IFN- $\alpha$ on mRNA Expression of Clock or Clock-Controlled Genes

A: 24-hour rhythm of mRNA expression for the $m$ Perl $1, m P e r 2, m C r y l$ and vasopressin gene in the SCN of mice continuously administered IFN- $\alpha(14 \mathrm{k} \mathrm{IU} / \mathrm{hr}$, s.c., O) or saline (O) using osmotic minipumps for 7 days. B: 24-hour rhythm of mRNA expression for $m P e r l$ and $d b p$ in the liver of mice continuously administered IFN- $\alpha(14 \mathrm{k} \mathrm{IU} / \mathrm{hr}$, s.c., O) or saline (O) using osmotic minipumps for 7 days. For plots of RNA, the mean peak value of the control group for $m P e r l$, $m P e r 2, m C r y 1$, vasopressin and Dbp is set at 100. Each point represents the mean \pm S.E.M. $(n=4-6) .{ }^{* *} p<0.01,{ }^{*} p<0.05$ compared to the value for the saline group at the corresponding zeitgeber times (Tukey's test). The horizontal bar at the bottom of the panels indicates the light and dark cycle.

作用の程度は投薬する時刻によって異なることを報 告した. ${ }^{20-23)}$ そこで IFN- $\alpha$ による生体リズムへの 影響を回避することを目的として, 時計遺伝子の発 現に及ぼす IFN- $\alpha$ 投薬タイミングの影響について 検討を行った. 実験には自由摂食飲水・明暗周期下 で飼育した ICR 雄性マウスを使用し, IFN- $\alpha(2.0$ MI.U. $/ \mathrm{kg}$ ）を明期前半（ZT0）又は暗期前半 （ZT12）のいずれかに6日間連日皮下投与した。 IFN- $\alpha$ を明期前半に投薬した際の視交叉上核におけ
るPer1 及びPer2 遺伝子の発現リズムは Saline 投 薬群と同様に有意な日周リズムが認められた。一 方, 暗期前半の投薬群においては, いずれの遺伝子 もピーク時における発現レベルが有意に低下し, 日 周リズムの振幅は著しく減少した（Fig. 7A）。また 同様に, CLOCK 及び BMAL1 遺伝子の発現レベル も暗期前半の投薬群において有意に減少し（Fig. 7B), CLOCK/BMAL1によるリズム発振力の低下 が Per 遺伝子発現リズムの振幅の低下に寄与してい 
A

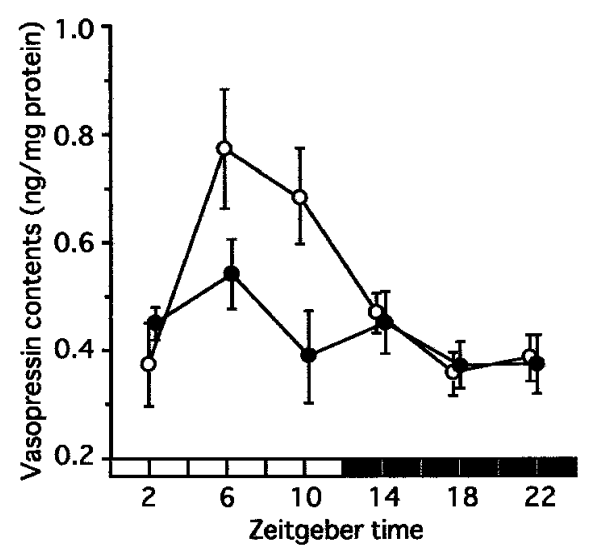

\section{B Saline}

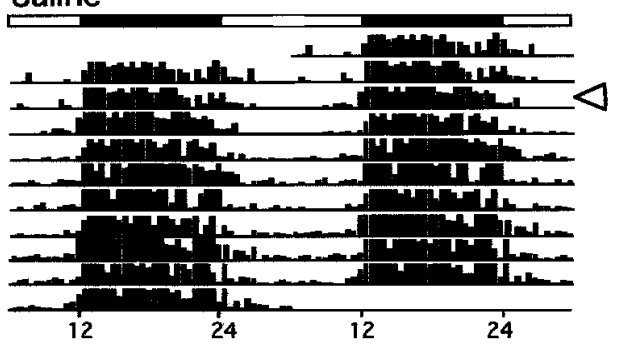

IFN- $\alpha$

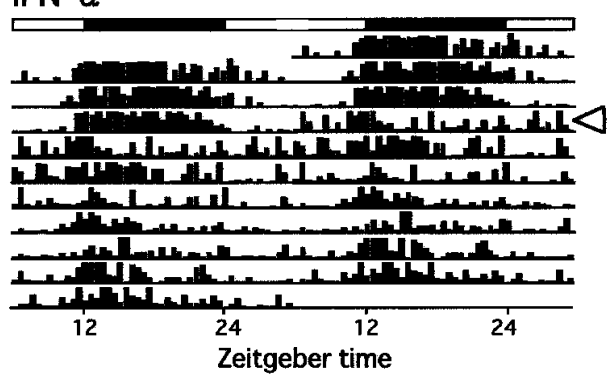

Fig. 6. Influence of IFN- $\alpha$ on the 24-hour Rhythm of SCN Vasopressin Contents or Locomotor Activity

A: 24-hour rhythm of vasopressin expression in the SCN of mice continuously administered IFN- $\alpha(14 \mathrm{k} \mathrm{IU} / \mathrm{hr}$, s.c., $)$ or saline $(\mathrm{O})$ using osmotic minipumps for 7 days. Each point represents the mean \pm S.E.M. $(n=$ $4-6$ ). The horizontal bar at the bottom of the panels indicates light and dark cycle. B: Representative locomotor activity records of mice continuously administered IFN- $\alpha$ (14 k IU/hr, s.c.) or saline using osmotic minipumps for 7 days. Open arrows indicate initiation of the drug administration. The horizontal bar at the top of each panel indicates the light and dark cycle.

る可能性が示唆された．さらにこれらの点と関連し て，IFN- $\alpha$ を明期前半に投薬した際，行動や体温の 日周リズムに影響は認められなかったが，暗期前半 の投薬群ではこれら生体機能のリズムに著しい変化 が認められ, 行動, 体温の日内変動はともに不明瞭 なものとなった. 以上の結果から, IFN- $\alpha$ による時
計遺伝子の発現リズムへの影響は投薬する時刻によ って異なり，生体リズムに及ぼす影響は至適投薬夕 イミングを設定することで回避可能になることが明 らかとなった。

\section{7. おわりに}

臨床上，多くの薬物が不眠や抑うつなど生体リズ ムの異常と関連の深い副作用を引き起こすことが知 られている。しかしながら，これら副作用を体内時 計の機能的変化として捉え, 積極的に回避しょうと する試みが行われているとは言い難い。特に通院に よる治療などの場合, 体内時計の機能低下は患者の 社会生活にも様々な弊害をもたらすことが予想され る.したがって，このような作用を有する薬物につ いては，正常なリズムを維持しながら治療を続ける ことが医薬品の適正使用の観点からも重要である.

本研究では生体リズム変容が，薬物を投薬する時 刻を考慮することで回避可能になることを明らかに した。時間薬物療法の基本的概念は，「体内時計」 という生体が元来兼ね備えた巧妙な仕組みを上手く 利用することによって, 従来の薬物療法をより効果 的，効率的に行おうとすることである．筆者らが明 らかにした一連の結果は, 投与量や投与間隔の調整 に主眼が置かれた従来の薬物療法に「至適投薬夕イ ミング」という新たな概念を取り入れることで，よ り安全で有効性の高い薬物療法が可能になることを 示唆している.また, Nature, Cell, Science などの 各科学誌は, 近年の発展著しい研究分野として, 体 内時計の分子機構を挙げている. 今後, この研究分 野の重要課題は臨床応用などへ向けた実践展開であ り, 時計遺伝子・生体リズムを基盤にした時間治療 研究の発展が期待される.

謝辞本研究を行うにあたり，ご指導とご支援 を賜りました諸先生方に厚く御礼申し上げます。ま た，ご協力いただきました共同研究者及び学生諸氏 に感謝の意を表します。

\section{REFERENCES}

1) Moore R. Y., Eichler V. B., Brain Res., 42, 201-206 (1972).

2) Gekakis N., Staknis D., Nguyen H. B., Davis F. C., Wilsbacher L. D., King D. P., Takahashi J. S., Weitz C. J., Science, 280, 1564- 

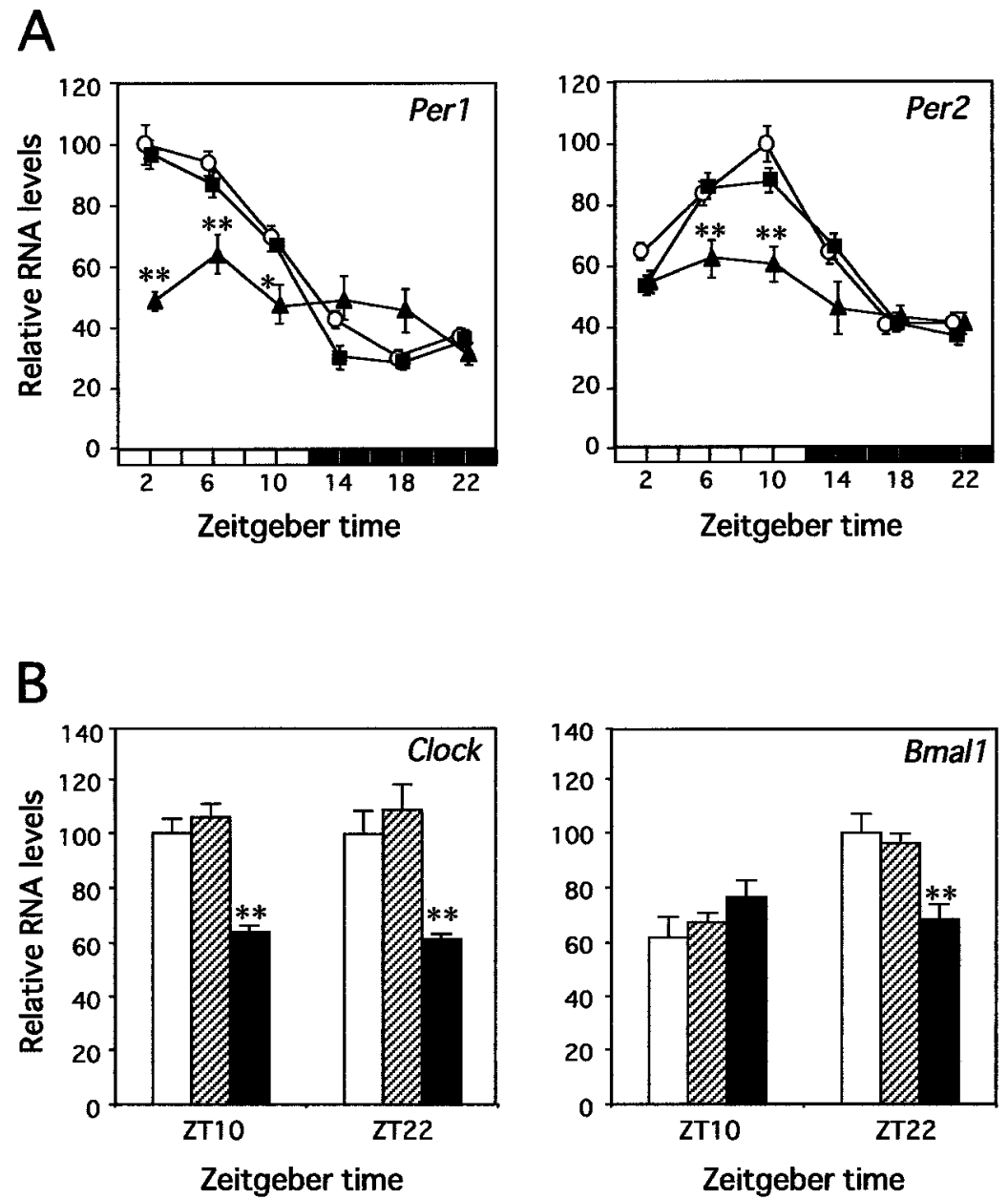

Fig. 7. Influence of IFN- $\alpha$ Dosing Time on mRNA Expression of Clock Genes

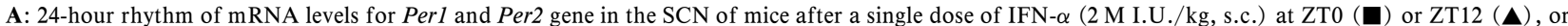
saline (O) for 6 days. B: Temporal profiles of mRNA levels for Clock and Bmall at ZT10 or ZT22 in the SCN of mice after a single dose of IFN- $\alpha$ (2 M I.U./kg, s.c.) at ZT0 $(\square)$ or ZT12 $(\square)$, or saline $(\square)$ for 6 days. Each valeu represents the mean \pm S.E.M. $(n=4-6) .{ }^{* *} p<0.01$ compared to the value of saline group at corresponding zeitgeber times (Tukey's test).

$1569(1998)$.

3) Kume K., Zylka M. J., Sriram S., Shearman L. P., Weaver D. R., Jin X., Maywood E. S., Hastings M. H., Reppert S. M., Cell, 98, 193205 (1999).

4) Albrecht U., Sun Z. U., Eichele G., Lee C. C., Cell, 91, 1055-1064 (1997).

5) Shigeyoshi Y., Taguchi K., Yamanoto S., Takekida S., Yan L., Tei H., Moriya T., Shibata S., Loros J. J., Dunlap J. C., Okamura H., Cell, 91, 1043-1053 (1997).

6) Winget C. M., DeRosha C. W., Markely C. L., Holley D. C., Aviat. Space Environ. Med., 55, 1085-1096 (1984).

7) Cho K., Ennaceur A., Cole J. C., Suh C. K., J. Neurosci., 20, RC66: 1-5 (2001).

8) Koyanagi S., Ohdo S., Mol. Pharmacol., 62,
1393-1399 (2002).

9) Ohdo S., Koyanagi S., Suyama H., Higuchi S., Aramaki H., Nature Med., 7, 356-360 (2001).

10) Sakamoto K., Nagase T., Fukui H., Horikawa K., Okada T., Tanaka H., Sato K., Miyake Y., Ohara O., Kato K., Ishida N., J. Biol. Chem., 273, 27039-27042 (1998).

11) Yamazaki S., Numano R., Abe M., Hida A., Takahashi R., Ueda M., Block G.D., Sakai Y., Menaker M., Tei H., Science, 288, 682685 (2000).

12) Jin X., Shearman L. P., Weaver D. R., Zylka M. J., Vries G. J. D., Reppert S. M., Cell, 96, 57-68 (1999).

13) Ripperger J. A., Shearman L. P., Reppert S. M., Schibler U., Genes Dev., 14, 679-689 
(2000)

14) King D. P., Zhao Y., Sangoram A. M., Wilsbacher D.L., Tanaka M., Antoch M. P., Steeves T. D. L., Vitaterna M. H., Kornhauser J. M., Lowrey P. L., Turek F. W., Takahashi J. S., Cell, 89, 641-653 (1997).

15) Bunger M. K., Wilsbacher L. D., Moran S. M., Clendenn C., Radcliffe L. A., Hogenesch J. B., Simon M. C., Takahashi J. S., Bradfield CA., Cell, 103, 1009-1017 (2000).

16) Darnell J. E. Jr, STATs, gene regulation, Science, 277, 1630-1635 (1997).

17) van der Horst G. T., Muijtjens M., Kobayashi K., Takano R., Kanno S., Takao M., de Wit J., Verkerk A., Eker A. P., van Leenen D., Buijs R., Bootsma D., Hoeijmakers J. H., Yasui A., Nature, 398, 627-630 (1999).

18) Bae K., Jin X., Maywood E. S., Hastings M.
H., Reppert S. M., Weaver D. R., Neuron, 30, 525-536 (2001).

19) Zheng B., Albrecht U., Kaasik K., Sage M., Lu W., Vaishnav S., Li Q., Sun Z. S., Eichele G., Bradley A., Lee C. C., Cell, 105, 683-694 (2001).

20) Ohdo S., Koyanagi S., Yukawa E., Higuchi S., Life Sci., 61, PL95-100 (1997).

21) Koyanagi S., Ohdo S., Yukawa E., Higuchi S., J. Pharmacol. Exp. Ther., 283, 259-264 (1997).

22) Ohdo S., Wang D. S., Koyanagi S., Takane H., Inoue K., Aramaki H., Yukawa E., Higuchi S., J. Pharmacol. Exp. Ther., 294, 488-493 (2000).

23) Takane H., Ohdo S., Baba R., Koyanagi S., Yukawa E., Higuchi S., Jpn. J. Pharmacol., 90, 304-312 (2002). 